\title{
How to use BMP-2 for clinical applications? A review on pros and cons of existing delivery strategies
}

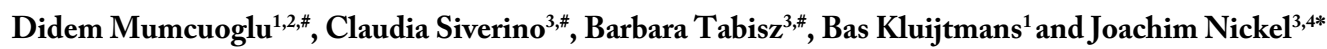 \\ ${ }^{1}$ FUJIFILM Manufacturing Europe B.V., P.O. Box 90156, 5000 LJ Tilburg, The Netherlands \\ ${ }^{2}$ Department of Orthopaedics, Erasmus MC, University Medical Center Rotterdam, The Netherlands \\ ${ }^{3}$ Wuerzburg branch of the Fraunhofer-Institute Interfacial Engineering and Biotechnology, IGB, Translational Center Wuerzburg 'Regenerative therapies in \\ oncology and musculoskelettal diseases, Roentgenring 11, D-97070 Würzburg, Germany \\ ${ }^{4}$ Chair Tissue Engineering and Regenerative Medicine, University Hospital Wuerzburg, Roentgenring 11, D-97070 Wuerzburg, Germany \\ \#These authors contribute equally to the work
}

\section{Introduction}

Healing of bone fractures describes a remarkable process in that the injured tissue heals without scar formation, thus typically resulting in a complete regeneration of the bone's anatomy and function [1]. Long bone fractures are reported to occur in the western world at an incidence rate of 300-400 cases per 100,000 individuals per year $[2,3]$ and heal in most cases without surgical intervention within 20 weeks [4]. The needs for a progressive union of bone fractures have been identified and defined as a so-called diamond shaped concept comprising the parameters: adequate cellular environment, sufficient growth factors, bone matrix and mechanical stability. Patients lacking one of these parameters might develop complications during the healing process, which subsequently can result in a delayed or even non-union of the fracture [5]. The incidence of non-union fractures has been reported to range from $4-10 \%[4,6]$. Non-union fractures are associated to reductions in the patient's general life quality but also to concomitant inconveniences and costs due to prolonged hospitalization and secondary interventions. It is therefore of great interest to develop new therapeutic concepts that positively affect bone healing.

In the past, the main focus for a regenerative stimulation of nonunion fractures was laid on the use of autograft, allograft, and xenograft bone. Of these, autografts were considered as golden standard as these are osteogenic, osteoconductive, and osteoinductive [7-9]. However, the use of autografts is limited due to the given volume quantities and due to donor site morbidities which are frequently observed and typically accompanied by chronic pain [10]. Other major complications which occurred upon extraction of autograft bone are vascular injuries, deep infections, or neurologic injuries at the donor site [11].

Another regenerative approach which recently gained attention as alternative to autograft bone in clinical settings is the use of platelet-rich plasma (PRP). This method in principle utilizes intrinsic growth factors of platelet concentrates in order to stimulate and accelerate a healing response [12]. However, despite the efficacy of PRP in in vitro and in vivo scenarios, its use and delivery in terms of bone regeneration have yet not been optimized. A significant drawback of such preparations is that optimal doses for administration as well as the identity of the active substances within the concentrates are largely unknown [13].

Extensive studies focusing on the underlying molecular mechanisms of fracture repair identified some specific factors to be involved in the healing process like parathyroid hormone (PTH), hypoxia-inducible factor 1a (HIF-1a), factors modulating the Wnt signaling pathway, and bone morphogenetic proteins (BMPs) [14]. The use of defined compounds like such growth factors allows more precise treatment of bone fractures and are financially advantageous since high amounts of these factors can be prepared in appropriate recombinant expression systems [15]. Here, the most ppromising growth factor candidates are bone morphogenetic proteins (BMPs), which were originally identified by their capabilities to induce the formation of bone when implanted at ectopic sites [16,17].

BMPs belong to the large TGF beta superfamily of secreted growth factors which play an important role in early embryonal development but are also crucial for the maintenance and regeneration of tissues and organs in the adult organism [18-20]. The existence of BMPs in all vertebrates as well as non-vertebrate animals highlights the importance of these factors for a multitude of biological processes, which recently gave rise to the suggestion to rename the term "bone morphogenetic protein" into "body morphogenetic protein" [21]. This renaming would also eliminate the misinterpretation that all BMPs are truly osteogenic. BMPs which indeed induce bone formation can be, based on sequence homology and receptor usage, divided into three subgroups, the BMP2, -4; the BMP-5, -6, -7; and the BMP-9, -10 subgroup, respectively $[22,23]$. Other proteins which are, based on a historical context, also called BMPs are either not osteogenic or their precise function has yet not been fully elucidated. For instance, BMP-1 (also known as Mammalian tolloid protein (mTLD) or Procollagen C-proteinase (PCP)) represents a metalloprotease and does not share structural similarities with other TGF- $\beta$ superfamily members [24]. Further examples are provided by BMP-3, BMP-13 (also known as GDF-6) and BMP-14 (also known as GDF-5) which function, at least partially, as BMP antagonists/inhibitors rather than being agonistic on their own [25-27].

Signal transduction by TGF- $\beta$ superfamily members is typically initiated by binding to two types of serine/threonine kinase receptor chains termed type I and type II [28-30]. Upon complex formation, the constitutively active type II receptor activates the type I receptor which subsequently leads to an activation of the so-called canonical

Correspondence to: Joachim Nickel, Chair Tissue Engineering and Regenerative Medicine, University Hospital Wuerzburg, Roentgenring 11, D-97070 Wuerzburg, Germany, Tel: 49 (0) 9313184122; Fax: 49 (0) 9313181068; E-mail: joachim.nickel@uni-wuerzburg.de

Received: July 14, 2017; Accepted: August 16, 2017; Published: August 19, 2017 
SMAD signalling pathway [31,32]. Disregarding cross-talks with other connected signalling cascades (like e.g. the MAP-Kinase signalling pathway) only two different SMAD pathways, the so-called SMAD2/-3 or the SMAD-1/-5/-8 pathway, are established. Which of the two canonical pathways finally gets activated solely depends on the individual type I receptor (the particular signalling receptor) being present in the signalling active ligand-receptor complex. Thus, within this superfamily a strong signal convergence starting from a manifold of ligands and ending principally in the activation of only two different SMAD signalling pathways is established which appears even more limited as far as osteogenic BMPs are concerned [33]. Despite differences in the preferential receptor usage observed for the particular osteogenic ligands, signalling occurs in all cases via the SMAD-1/-5/-8 pathway. For BMP-2 and $-4-10$, signalling is mediated by the type I receptors (BMPR-IA or IB) whereas the BMP-5/-6/-7 subgroup utilizes ActR-I (Alk2) for signalling (for review, see Katagiri et al. [34]). For BMP-9 high affinity binding to ALK1 has been reported but signalling can also occur via ActR-I [35]. The obvious discrepancy between the number of ligands (more than $20 \mathrm{BMP}$ members have been identified in mammals to date) and the limited amount of receptors raises important questions especially how these proteins can share so many different cellular functions and furthermore how those can act as morphogens during embryogenesis. Different temporal and/or spatial expression patterns might best explain this issue but since double knock-outs of ligand genes often lead to more severe phenotypes than observed for the individual single knock-outs the existence of at least partial compensation must be taken into consideration. It therefore seems plausible that cellular signalling is modulated massively at several cellular levels (for review see Nickel et al. [33]). Extracellularly socalled modulator proteins (e.g. Noggin, Chordin, etc.) can bind to the ligand thereby preventing its interaction with the receptors as shown for Noggin [36] or Follistatin [37]. Thus, ablation of the interaction of the osteogenic factors to Noggin also indirectly increases the osteogenic potential of the particular ligand [38].

Aside from these modulators, the biological activity of BMP-2 or -7 is also regulated by their capability to bind to components of the extracellular matrix (ECM) such as heparin or heparan sulfates $[39,40]$. In vivo, the ECM seems to function as reservoir by adsorbing the ligands from the three-dimensionality of the interstitial liquid thereby increasing the ligands concentration on the cell surface. The matrix serves as a store allowing a slow release of the ligand over prolonged periods of time. Hence modulating the binding strength of the growth factors to the ECM could result in altered bioactivities which indeed has already been observed in vitro and in vivo [41].

Taken together, the different aforementioned parameters which concertedly define the particular ligand's osteogenic potential have been addressed in several pre-clinical and clinical trials. They generally aimed to produce osteogenic formulations allowing the application of the growth factor to defect sites. For that purpose, they use systems which concomitantly control the factor's release to achieve sufficient high local concentrations over the period of time needed to heal the defect.

This review sheds light into the design of the different systems to deliver BMP-2 for in vivo applications. As outlined above, the control over the growth factor's bioactivity and spatial-temporal presence is obviously crucial for bone healing but seems extremely difficult to achieve.

Growth factors like BMP-2 can principally be brought to injured site in two different ways. At first, DNA that encodes for the particular growth factor can be delivered either in form of a suitable expression plasmid or integrated into a viral particle or the genetic information is already introduced into an acceptor cell's genome in order to express the particular growth factor at the site of action. As second method, the gene product, i.e. the recombinant expressed growth factor itself or peptide mimicking its specific bioactivity, is applied ectopically to the injured site. For an overview, see Figure 1.

Gene therapy offers a multitude of different applications ranging from cancer to various infectious diseases, cardiovascular or other monogenic disorders. Due to its generic potential, over 1800 clinical trials involving gene therapy were conducted by 2012 [42]. Also in bone regeneration the potential of gene delivery is still under investigation. Principally, as mentioned before the genetic information can be delivered by a vector to the injured site where cells will take it up and start protein expression, or by the delivery of cells that are already transfected with an appropriate vector ex vivo which, after implantation, will express the protein at the site of injury.

In the following, both techniques are discussed in detail comparing the feasibility and drawbacks of each technique in scope of bone regeneration by application of the best investigated osteogenic factor, BMP-2, as well as potential ways to further improve each technique.

\section{BMP-2 delivery using BMP-2 encoding cDNAs}

\section{General aspects of various DNA delivery methods}

The choice of the growth factor to be expressed is very important since the single gene to be delivered, here that of BMP-2, must initiate an apparently high complex process resulting finally in the full restoration of the bone defect. For more complicated cases (e.g. where a large defect area needs to be repaired) gene delivery of a combinations of BMP-2 along with factors of other growth factor families (e.g. VEGF) [43] or combinations of BMP-2 and transcription factors (e.g. BMP-2 and Runx2) seems advantageous [44]. Co-expression of BMP-2 and transcriptional factors being specific for bone tissue

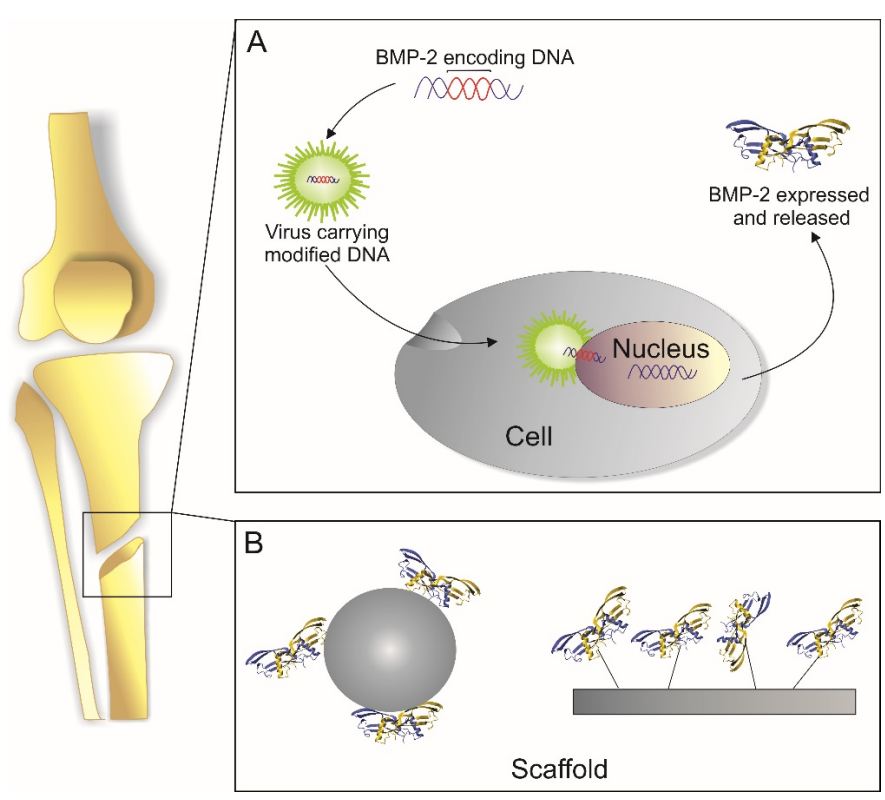

Figure 1. Main principles for growth factor delivery

(A) cDNA encoding for the desired growth factor is introduced into the cells e.g. via plasmids or viral vectors and is translated and secreted at the site of injury. (B) The protein is deposited at the site of injury in a form of depot e.g. in form of functionalized scaffolds. 
such as Runx2 might provide more efficient bone regeneration since it regulates expression of other osteogenic factors that drive e.g. the osteogenic differentiation of mesenchymal stem cells [45]. However, the osteogenic gene to be delivered is not the only parameter to be considered. Also the choice of the vector or the matrix that will determine the transfection efficiency of the gene and the residence time is equally important. A major concern of gene therapy is the stable and controllable overexpression of the delivered gene. In order to prevent extreme expression levels, which in terms of BMP-2 delivery might result in unwanted off-target effects, constructs with inducible promoters - such as tetracycline-sensitive promoters (TetON) - might be favorable [46].

In general, the vectors that are used for gene therapy can be subdivided into two classes: viral and non-viral vectors. The use of viral and non-viral vectors for tissue engineering has been reviewed elsewhere [47-49] but advantages and disadvantages of the particular expression systems are important to note. Viral vectors - as the name suggests - are derived from viruses (i.e. adenovirus; lentivirus) and have higher transfection efficiencies than non-viral vectors. However, due to safety concerns, the use of viral vectors in clinics is still under debate. Safety concerns address immunogenicity of particular viruses which indeed differ amongst different virus types. The adenovirus, which was one of the first used vector systems for gene delivery, may induce inflammatory or antigenic responses due to expressed viral hull proteins [50], whereas adeno-associated viruses (AAV) are considered to be safer since viral proteins are not expressed in the receiver cell (for review, see Buning et al. [51]). On the other hand, retroviruses or lentiviruses might induce insertional mutagenesis which limits their general potential for gene therapy. The use of adenovirus or AAV in bone regeneration at this stage seems more feasible since it poses less risks and it provides transient expression for several weeks matching the time frame for bone defect to heal [47].

Due to the mentioned safety concerns, a promising alternative relies on the use of liposomes that act as a vehicle for non-viral vectors (plasmids) and might reach adequate efficacy with coincident lower risks compared to viral vectors. Besides safety, liposomes are easy to prepare and their use is not constrained by the size of the used DNA [52]. Both, viral or non-viral vectors can be applied to the injury site either directly or embedded within a matrix/scaffold.

\section{Delivery of BMP-2 encoding genes by direct injection of viral or non-viral vectors or by application of DNA-functionalized matrices}

Different DNA delivery methods have been investigated in vivo using different animal models. In rodents, the injection of adenovirus carrying the BMP-2 gene resulted in successful delivery and as a result of BMP-2 over-expression improved osteogenesis in the defect area could be observed [53]. However, in other animal studies the same adenoviral system failed [54]. In these cases, a high level of BMP-2 expression was observed within the first week after implantation which strongly decreased in the following weeks. Inflammatory cells were found in the defect area which showed an immune response against BMP-2 and/or the adenoviral vehicle which might explain the observed retardation of osteogenesis [54]. This study revealed the importance of larger animal studies before conducting clinical trials which is also recommended by FDA guidelines [55].

In order to improve the efficacy of the applied vehicles, they might be shielded from the recipient's immune system using so-called stealth
(PEGylated) liposomes. Another method to increase the transfection efficiency of the vehicle relies on the use of cell penetrating peptides (CPPs) [56]. Also targeted delivery of the vehicles specifically to bone tissue would result in a homing of the transgene to the defect site. A very interesting new idea for efficient gene delivery is based on "designer" histones serving as targeting molecules thus aiming to improve the osteogenic capacity of growth factors [57]. Taken together, more sophisticated designs of vectors (e.g. with stealth liposomes, CPPs, inducible systems or targeting molecules) hold more potential if used in direct gene delivery approaches. But, the development of suitable delivery systems is not easy since the individual design strongly depends on the application itself and the clinical outcome of such a complex design is hard to predict. Different ways to improve gene delivery systems in general are detailed elsewhere [58] but one important improvement to be noted relies on the encapsulation of the vector within a biomaterial or functionalizing the material's surface with DNA encoding for the desired protein [58]. Those matrices are called "gene-activated" matrices (GAMs) and their applications have been extensively tested either in a form of hydrogels [59] or implant coatings [60]. In one example, BMP-2 encoding cDNA was embedded within alginate hydrogels which serves as a potent transfection agent and as a good scaffold material at the same time [61]. Advantages of such matrices are the long shelf-life of the material (possibility of freeze-drying), and ability to function as a defect filler [49].

For the regeneration of more complex tissue structures like the bone-cartilage interface, scaffolds comprising two layers were designed, one of which consisted of a "chondrogenic plasmid" (TGF- $\beta 1$ )functionalized chitosan-gelatin and the other an "osteogenic plasmid" (BMP-2)-functionalized hydroxyapatite/chitosan-gelatin [62]. Mesenchymal stem cells were also seeded in each layer of the gene activated matrix. Detailed analyses of this system revealed that the used stem cells differentiate towards chondrocytic or osteoblastic lineages depending on the layer they were positioned. Furthermore, a successful regeneration of an osteochondral defect could be achieved using this construct in a rabbit knee model.

The different natural or synthetic scaffold materials being used for bone regeneration are not in scope of this review article. However, since the scaffold also actively takes part in the regeneration process, the characteristics of each biomaterial should be considered, compared and selected for a specific application. Among different natural polymers, insoluble collagen-based bone matrices (ICBM) have been widely used which is based on the fact that that bone organic matrix principally consists of collagen (90\%) [63]. The drawback of this matrix relies on remnants of immunogenic molecules that might challenge the host's immune system. Other natural matrices which are represented by in situ gelling systems like alginates or peptide nanofibers are injectable, thus allowing easy filling of the defect area. Although a matrix is important to fill the defect area and localize cells and growth factors at the site, it does not always result in better healing process which depends strongly on the chosen scaffold. For instance, in a study where either untreated or adenoviral transduced cells expressing BMP-2 were injected either directly or embedded within alginates into a bone defect in nude rats, the alginate scaffold clearly impeded BMP-2 induced bone formation [64]. This study nicely demonstrates that parameters like the choice of the cells to be introduced or the selected scaffold material only seem to fine-tune the outcome of the individual experiment but the initial trigger of this complex process is provided by the applied osteogenic growth factor. 


\section{Gene delivery by cells ex vivo transfected with BMP-2 encoding cDNAs}

Cell mediated gene therapy is another approach in which cells are transfected ex vivo with the cDNA encoding for the desired growth factor and are subsequently administered to the injury site for tissue regeneration. The disadvantages of cell based gene therapy compared to acellular approaches are related to costs and also the necessity to obtain sufficient amounts of suitable autologous cell material. Furthermore, the procedure is more difficult to perform than the before mentioned acellular approaches, it is more time-consuming due to the necessity to expand the autologous cells. Additionally, the work has to be done according to the guidelines of Good Manufacturing Practice (GMP). However, there are also noteworthy advantages, since the delivered cells themselves might actively participate in the regeneration process. Due to complications associated with allogenic cell sources, the use of autologous cells is the gold standard in the clinics so far [65]. But, there is also a drawback of this technique. An additional treatment or surgery is required in order to obtain these cells being often accompanied by a significant tissue morbidity at the site of explantation [66]. The current practices and studies in bone and cartilage regeneration generally involve mesenchymal stem cells (MSCs) derived either from bone marrow or other sources. Owen and co-workers already showed in the late 1980s that bone marrow derived stem cells (BMDSCs) can be differentiated towards different cell types including bone [67]. More recently, an alternative, powerful method was established to re-program non-stem cells to so-called "induced pluripotent stem cells" (IPSCs). Here, somatic cells (e.g. adipocytes which can be obtained easily by liposuction) are dedifferentiated to so-called induced pluripotent stem cells (iPSCs) which subsequently are again differentiated to MSCs [68]. This new method is not yet in clinical use, but first clinical trials using IPSCs for macular degeneration have been initiated in Japan [69]. In one of the early clinical studies addressing the treatment of bone disorders, the transplantation of allogenic MSCs has been investigated in children with osteogenesis imperfecta. In this study, the allogenic BDMSCs were shown to improve the velocity of bone growth in five of the six patients [70] which led to several follow-ups in the field of bone regeneration. Recently, a clinical trial has investigated the effect of BMDSCs for craniofacial bone regeneration. Here, accelerated alveolar bone regeneration could be observed in a jawbone defect thereby eliminating the need for secondary bone grafting [71]. While usage of BDMSCs progresses in clinical trials aiming for bone regeneration, pre-clinical studies already involve MSC-based gene delivery. In one of these pre-clinical studies, bone marrow derived cells were co-transfected with cDNAs encoding for BMP-2 and vascular endothelial growth factor-165 (VEGF-165) in order to induce bone regeneration by means of BMP-2 mediated osteogenesis and VEGF mediated angiogenesis [72]. The cohort expressing both growth factors simultaneously was found to be better in terms of the formation and deposition of newly formed bone compared to the cohorts expressing only one of the two growth factors in rabbit orbital defect model [72]. The delivery of VEGF in combination with the osteogenic BMP-2 induces neo- vascularization of the newly formed bone tissue thus enabling superior supply of nutrients [73].

Harvesting bone marrow is not an easy procedure since it often causes post-operational pain. Therefore, alternative stem-cell sources, such as adipose tissue, have been intensively investigated. In a study employing BMP-2 transfected adipose stem cells, their potential for bone regeneration was clearly demonstrated. When rats were treated with the transfected stem cells being embedded into alginate gels, complete bone healing was observed in a cranial defect model [74]. Thus, due to the easy of collection adipose tissue derived stem cells are preferred over BMDSCs at least for this application.
However, most of the clinical trials utilizing MSCs for bone regeneration were not successful. Meijer et al. [65] stated possible reasons and identified important parameters as the number of cells with osteogenic capacity, the bio-compatibility of the used scaffolds, the presence of osteogenic factors, and vascular supply. Furthermore, it was also reported that results of pre-clinical trials in most cases could not serve as layout for the clinical studies since differences in e.g. the regeneration time of rodents and humans produced different experimental outcomes [65].

In MSC mediated gene delivery, one of the critical issues is the localization of the modified cells, and consequently the localization of the expressed protein. However, when MSCs were injected, it was observed that the injected cells do not easily home to bone and $98 \%$ of the injected MSCs are lost through liver and spleen [75]. To overcome this problem, the cells might be transfected to co-express an osteogenic growth factor like BMP-2 along with bone-homing proteins e.g. CD49d [76].

\section{Delivery of recombinant BMP-2}

\section{General aspects}

Growth factors which can be delivered to the site of injury might recruit endogenous stem cells to the site of action which upon exposure to the ligand undergo differentiation, thus inducing bone healing in situ. An FDA approved product, INFUSE ${ }^{\bullet}$ Bone Graft, which contains BMP-2 being adsorbed to a collagen sponge has been clinically used in spinal cord injuries. However, some adverse events such as infections, severe swelling, heterotopic ossification or urogenital problems have been observed after surgery [77-79] which are discussed to be related to the supraphysiological amounts of the growth factor being administered. This leads to the hypothesis that these adverse events might be eliminated by reducing the delivered growth factor amount to a suitable yet clinically relevant dose. Therefore, the development of a delivery system that provides a sustained release of the protein at sufficient concentrations is a challenge of high priority. An overview on the various BMP-2 delivery strategies is depicted in Figure 2. These strategies will be discussed in more detail in the next sections.

A

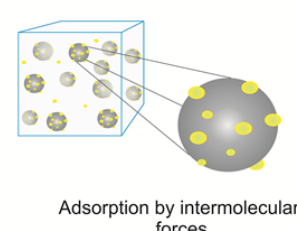

C

B
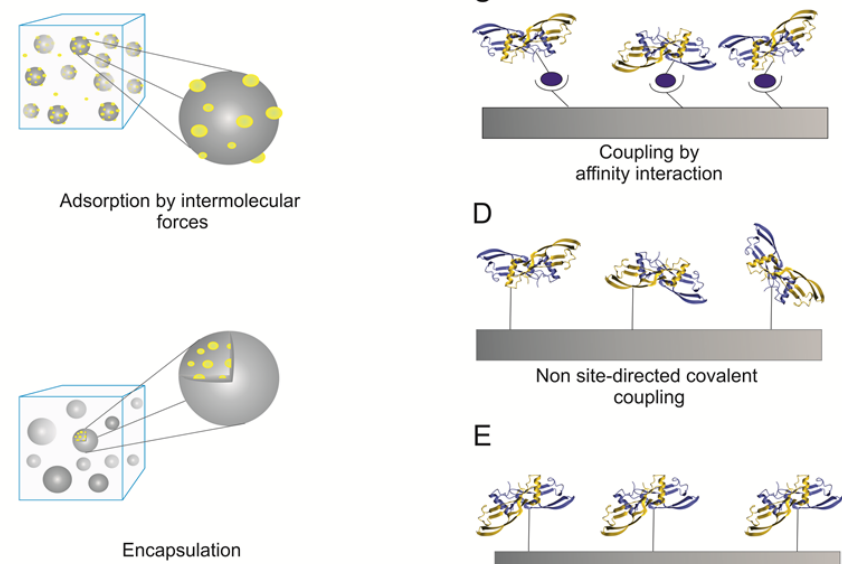

D

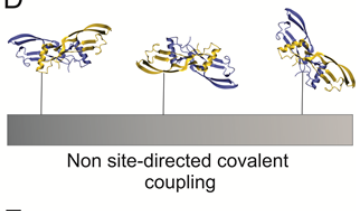

E

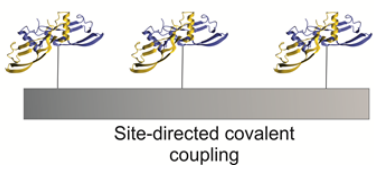

Figure 2. Delivery strategies for recombinant expressed BMP-2 or BMP-2 variants

The cartoons illustrate the different immobilization strategies as indicated (A) BMP-2 can be adsorbed to solid surfaces or incapsulated into e.g. hydrogels (B). Higher coupling specificities can be achieved by affinity interactions e.g using biotinylated BMP-2 being coupled to strepavidin coated matrices (C). Covalent coupling can be achieved non sitedirected to structures being activated e.g. by NHS esters (D) or site-directed via click chemistry $(\mathbf{E})$. 


\section{Non-covalent binding strategies}

Delivery of encapsulated or adsorbed BMP-2: In vivo, growth factors interact with receptors present on the cell surface in a noncovalent manner. The signalling molecule, such as BMP-2, is in most cases soluble (i.e. not membrane bound) and thus can diffuse or be actively transported to responsive cells. Therefore, many research laboratories emphasized on non-covalent binding strategies which utilized growth factors being adsorbed to or encapsulated in a broad variety of suitable scaffold materials.

Natural polymers such as collagen have several advantages. For example, they have endogenous enzyme cleavage sites and the degradation time of the material follows the endogenous remodelling time of collagenous tissues. Collagen sponges represent the earliest and best studied materials used for BMP-2 delivery. A disadvantage of this material relies on so-called early burst effects which are often observed upon administration [80]. In order to obtain a sustained release of the protein and decreasing this initial burst release phenomenon, genipin-crosslinked gelatin microparticles have been designed. Gelatin microparticles showed lower burst releases compared to poly(lacticco-glycolic acid) (PLGA) microparticles in vitro. A composite scaffold of these gelatin microparticles embedded in poly(propylene fumarate) (PPF) showed a sustained release of BMP-2 in vivo in a subcutaneous mouse model. This study also demonstrated that microspheres encapsulated within a scaffold provide a better control of growth factor release compared to the scaffold alone [81]. In order to produce fully synthetic biodegradable materials, mimics of natural polymers such as collagen have been designed. In one of these studies, matrix metalloproteinase (MMP) cleavage sites and RGD (ArgGly-Asp) moieties were introduced into polyethylene glycol (PEG) polymers. Here, the release of BMP-2 was shown to be induced by MMP-2 mediated degradation in vitro. The effect of these hydrogels containing $5 \mu \mathrm{g}$ of BMP- 2 on bone healing was studied using criticalsized calvarial defect model in rats. The MMP-sensitive, BMP-2-loaded hydrogel induced formation of new bone comparable to BMP-2 loaded collagen sponges (Helistat ${ }^{\circledR}$ ) [82]. Another more complex material which was also studied in the context of bone regeneration, is a MMP cleavable PEG hydrogel functionalized with an $\alpha 2 \beta 1$ integrin-specific peptide (GFOGER; single letter amino acid code, $\mathrm{O}=$ hydroxyprolin). This material was shown to be effective for bone-healing in a mouse critical size defect model even in the absence of BMP-2 but doping the hydrogel with low BMP-2 doses $(0.03 \mu \mathrm{g})$ resulted in higher bone formation capabilities and complete bridging of bone gaps after 8 weeks [83]. Hybrid nanofiber mesh/alginate delivery systems containing RGD (Arg-Gly-Asp) have been compared to collagen sponges for BMP-2 release [84]. Bone formation at 8 weeks post-surgery was significantly increased in the nanofiber mesh/alginate group compared to the collagen sponges at the same dose $(1.0 \mu \mathrm{g}$ rhBMP-2). In order to obtain 3D scaffolds with defined and reconstructable structures, Lee et al. [85] created polymeric 3D scaffolds by solid free-form fabrication (SFF) technology, computer-aided design (CAD) and computer-aided manufacturing (CAM) techniques. BMP-2 loaded microspheres were encapsulated within these microstereolithography-produced scaffolds and after 7 days BMP-2 started to be released linearly. When the performance of the construct was studied in a rat cranial bone defect model, around 75\% bone formation was observed after 11 weeks [85].

The detailed description of the results, using different combinations of BMP-2 and materials as mentioned before, led to the assumption that the material type has a major impact on the success of bone regenerative approaches. These material related effects become obvious by comparing e.g. brushite and PLGA controlled release systems loaded with the same doses of BMP-2. PLGA appeared significantly more osteogenic than brushite which is attributed to the slow resorption rate of brushite [86]. As a consequence, BMP-2 is not released in sufficiently high concentrations which might indicate the requirement of an at least minimal burst release. On the other hand, the hard brushite material might also impede the migration of invading cells which are essential for the process of bone regeneration.

Delivery of BMP-2 utilizing affinity interactions: One of the strategies for protein immobilization relies on affinity interactions of specifically tagged proteins with appropriately functionalized surfaces. Unlike covalent coupling, affinity interactions are weaker, with the strength depending on the particular interaction partners. In most cases, the interaction can be affected e.g. by changing $\mathrm{pH}$ values, the temperature of the solution, or by using a competitive ligand. In vivo, these parameters can certainly only be altered to a limited extent. However, there are profound advantages of such approaches relying on a high specificity of the interaction, a mainly uniform orientation of both interacting partners, mild coupling conditions and a broad availability of various commercially available affinity tag systems. Reversibility of affinity interactions may be advantageous when the controlled release of the growth factor is crucial, for instance if the ligand has to be internalized from the effector cell to gain full signaling capabilities.

Nevertheless, there are also some limitations that one needs to consider when choosing the affinity-tag coupling strategy, such as laborious protein engineering, overall cost of affinity ligands, the possibility of changing the proteins properties, an unpredictable release of the immobilized growth factor or limited possibilities for tag positioning. Usually affinity tags are placed on either $\mathrm{N}$ - or C-terminus of a protein to minimize changes in its biological activity. Though, positioning of an affinity tag at either the $\mathrm{N}$ - or C-terminus of the protein sequence may be in some cases detrimental for its trafficking and folding.

Common affinity immobilization approaches can be performed via a vast number of different molecular fusion tags, such as small chargebased (poly-arginine or poly-histidine-) affinity tags, epitope tags based on the interaction with antibodies (hemaglutinin (HA), Myc, FLAG ${ }^{\mathrm{m}}$, V5 epitope), protein fusion tags (Protein A, Small Ubiquitin-related MOdifier (SUMO), glutathione $S$-transferase (GST), maltose binding protein $(\mathrm{MBP})$, calmodulin binding protein $(\mathrm{CBP})$, certain protein domains (cellulose binding domain, chitin binding domain), biotinylation (based on strong biotin-avidin affinity), and many others [87-90].

As already mentioned, BMP immobilization has been broadly exploited in terms of physical adsorption, encapsulation and nonspecific covalent immobilization. Nevertheless, addition of fusion tags was in context of BMPs employed mostly for protein purification (histag [91], maltose binding protein [92]), or detection and enrichment purposes [93, 94], and only in a few cases designed to enable a more permanent immobilization on scaffolds. Insertion of any kind of tag within the mature part of thr BMP sequence is strongly restricted to the N-terminus, which is caused by the buried architecture of its C-terminal end. Because of the specific domain arrangement of BMP proteins comprising a pro- and a mature-domain, insertion of any tag used in an eukaryotic heterologous expression system is thus strongly restricted to the $\mathrm{N}$-terminal end of the mature part as well which might impose hindrance in the intracellular protein trafficking and proper processing of the mature peptide. 
BMP-2 immobilization via His-tags: One of the best explored affinity tags used in protein science is a strain of 6 histidines, demonstrating a high affinity towards bivalent metal ions. An application for BMP-2 immobilization via an introduced his-tag was reported by Zhao et al. [95]. BMP-2 was expressed as fusion protein with 6 histidines (his6-tag) fused to the $\mathrm{N}$-terminal end of the mature part of human BMP-2. $10 \mu \mathrm{g}$ of the tagged BMP-2 protein was loaded onto a demineralized bone matrix (DBM) which was covalently decorated with pentahistidin antibodies (so-called MAbs-DBM). The antibodies were used to enhance the loading capacity of the demineralized scaffold. These scaffolds were subsequently tested in cell based assays for osteogenic differentiation using C2C12 cells and also in vivo for inducing ectopic bone formation in male Sprague-Dawley rats. The results clearly showed that his-tag immobilized BMP-2 was able to induce alkaline phophatase (ALP) activity in C2C12 cells in a dose dependent manner independent of whether it was adsorbed to the undecorated demineralized scaffold or bound to the pentahistidin antibody decorated scaffold. However, his-tag-BMP-2 bound to MAbsDBM induced higher ALP signals at the same BMP-2 dose. In vivo, after two weeks of implantation his-tag-BMP-2/DBM and His-BMP-2/ MAbs-DBM both induced formation of ectopic bone in proximity to the scaffolds which could not be observed in case of unloaded scaffolds. Moreover his-tag-BMP-2/MAbs-DBM revealed thicker layers of bone tissue and higher levels of calcification [95].

BMP-2 immobilization via bi-functional peptide linkers: Hamilton and co-workers have recently established a phage display procedure for the isolation of short bi-functional collagen and BMP-2 binding peptides [96]. For this purpose, they employed a biotinylated BMP-2 (linked by conventional N-Hydroxysuccinimid(NHS)-coupling techniques), which was then immobilized to a streptavidin-coated 96well microplate. Ten different phage display libraries, designed with a central specific amino acid core motif were screened for peptides that bind to BMP-2. The identified BMP-2-binding peptides were then individually combined with a collagen-binding peptide sequence (generated in previous work [97]) by a flexible linker. Such bifunctional peptides were mixed with BMP-2 supplied with an injectable collagen gel. The osteogenic properties of the construct $(200 \mu$ l of collagen gel containing $2 \mathrm{mg}$ of BMP-2) were investigated in vivo. Two weeks after surgery approximately $25 \%$ of the implant was covered with new bone in the peptide-containing group, whereas no bone formation was observed in the control group (without the bi-functional peptide). Further analyses revealed that binding of the BMP-2-binding peptides to BMP-2 was not affected by the presence of human plasma since plasma components theoretically could interact and thus compete for the binding of the peptide to BMP-2 [96].

BMP-2 immobilization via interaction with heparin/chitosan: Heparin, also known as a heparan sulphate is a highly sulfated glycosaminoglycan, carrying a strong negative surface charge. It is stored mainly in mast cells of the immune system and appears in the extracellular matrix of eukaryotic cells where it interacts with multiple growth factors and serves as an antibacterial and hydrating factor for the cellular matrix [98]. Owing to its strong affinity towards BMP-2, a number of BMP immobilization approaches using heparin/heparinbinding-site interaction emerged in the recent years.

In a paper by Kim et al. [99] titanium dental implants were covalently covered with heparin by using classical EDC/NHS-mediated coupling chemistry. The work focused on the development of a dental implant with antibacterial properties and enhanced osteogenic function. The BMP-2 binding to the heparin-grafted titanium discs was accomplished by immersing it in a BMP-2 solution (10 or $50 \mathrm{ng}$ / $\mathrm{mL}$ ) for $24 \mathrm{~h}$ at ambient temperature. In vitro tests showed reduced inflammatory potential as analyzed in a murine macrophage cell line, a sustained release of BMP-2 from the heparin-titanium discs and stimulated osteoblast function which was further proven by significantly higher ALP activities and calcium contents in cells grown on BMP-2 (50 ng)-immobilized titanium surfaces. Similar approaches to functionalize titanium surfaces were performed by Lee et al. and reported in 2012 [100].

Also recently, a similar approach for BMP-2 immobilization on polycaprolactone fibers was published in which their potential to induce osteogenic differentiation of periodontal ligament cells was studied [101]. The polycaprolactone fiber surface was functionalized with heparin-dopamine and further coated with BMP-2. The publication reports sustained BMP-2 release profiles over 28 days with no evident cytotoxicity against periodontal ligament cells (PDLCs). Fibers with immobilized BMP-2 significantly induced osteogenic differentiation with a significant increase in ALP activity, calcium deposition and mRNA expression levels of osteocalcin and osteopontin compared to the unmodified PCL fibers [101]. A subsequent in vivo study demonstrated that the implanted BMP-2/Hep-DOPA/PCL/ PLGA scaffolds implanted into rat femur defects induced more bone formation compared to that of BMP-2/Hep/PCL/PLGA- and PCL/ PLGA scaffolds [102]. Similarly, BMP-2 has also been immobilized onto calcium coated chitosan scaffolds [103]. These in vivo studies were performed in New Zealand male rabbits. Defects of $4 \mathrm{~mm}$ in diameter were drilled into tibiae maesetae of both legs and the scaffolds were implanted into the deficient area. The osteogenic potential of the scaffold was analysed 3 weeks after implantation. The results showed that BMP-2 remained active in the chitosan scaffolds and its release kinetic was dependent on the presence of calcium phosphate salts. Chitosan scaffolds containing both calcium phosphate salts (CPS) and BMP-2 were more osteoinductive than their counterparts alone [103].

BMP-2 immobilization via biotin-streptavidin interactions: $\mathrm{A}$ complex of biotin bound to streptavidin is the strongest known noncovalent biological interaction, with a dissociation constant $\left(K_{\mathrm{D}}\right)$ of 10 ${ }^{13} \mathrm{M}$ [104]. The complex formation is robust and binding may only be disrupted by harsh, denaturing conditions. For this reason biotin and streptavidin are a very convenient choice for protein immobilization. In context of BMP-2 immobilization, biotin-streptavidin interaction has been used to study the biological activity of bound BMP-2 [105], as well as for quantifying small amounts of immobilized BMP-2 on various materials [106]. Recently, a continuous surface BMP-2 gradient was constructed using biotin-streptavidin interaction, to enable cell screening studies [107]. However, since the production of streptavidin is cost-intensive, such approaches were in the past mainly addressed in basic research for e.g. protein purification or protein quantification.

BMP-2 immobilization via synthetic oligonucleotides: In an in vitro study conducted by Schliephake and co-workers [108] a set of complementary DNA strands was used for BMP-2 immobilization. The aim of the study was to investigate whether oligonucleotides could be suitable to immobilize and slowly release osteogenic growth factors, and thereby enhance the osteogenic potential of titanium implants. 60mer non-coding DNA oligonucleotides were fixed to titanium surfaces by anodic polarization. Conjugation of BMP-2 with complementary sequences was achieved by chemical crosslinking using disuccinimidyl suberate (DS) as linker molecule. The functionalized BMP-2 was then hybridized to the titanium-anchored oligonucleotides at room temperature (the coupling scheme is similar to that of biotinylated 
BMP-2 interacting with strepatavidin, see figure $2 \mathrm{C}$ ). In vitro experiments were performed using human bone marrow stromal cells (hMSCs). Release studies over 28-days showed a continuous release of BMP-2 from the titanium surface. Also proliferation of cells was significantly increased and the osteogenic markers, osteopontin and alkaline phosphatase, were upregulated. Additionally, BMP-2conjugated scaffolds revealed significantly higher number of focal adhesion points. Released BMP-2 was tested for its biological activity which was shown to be comparable to non-conjugated BMP-2, proving that the conjugation process did not affect its biological activity.

As many affinity binding approaches clearly showed that an increase of the affinity of BMP-2 to particular scaffolds enhances the osteogenic potential of the construct, several research groups have focused on covalent binding of the growth factor onto various materials.

\section{Delivery strategies using covalently coupled recombinant BMP-2}

Most of the injectable BMP carriers are unable to retain BMP at the site of injection. As a consequence, most carriers lose $50 \%$ or more of pre-loaded BMP after a few days in vivo. The delivery of a covalently immobilized growth factor would therefore offer the advantage of a controlled and sustained influence on cell behavior in comparison with soluble or slowly released proteins.

Implanting constructs being functionalized with covalently bound BMP-2 [109] demonstrated the easy delivery of this growth factor with a homogeneous distribution on the implant surface, primarily circumferential bone induction, rapid gap filling by trabecular bone within 4 weeks and an easy control and avoidance of ectopic bone formation. Covalent immobilization of BMP-2 and epidermal growth factor (EGF) has also been achieved on titanium dioxide $\left(\mathrm{TiO}_{2}\right)$ nanotube surfaces by N,N-carbonyldiimidazole (CDI) coupling either via direct binding to amine groups of the growth factor or via spacers such as 11-hydroxy-undecylphosphonic acid (PhoA) [110]. Coupling proteins via $\mathrm{N}, \mathrm{N}$-carbonyldiimidazole is non-site directed and may result at least partially in deactivation or denaturation of the coupled proteins. BMP-2 coating did not contribute to cell proliferation, attachment, adhesion or proliferation as shown for EGF if exposed to bone marrow derived MSCs. These findings indicate that these cellular activities are not trigerred by BMP- 2 or that the cells in general might be BMP-2 insenstive.

Since naturally occurring growth factors only contain a limited subset of reactive groups ( $\mathrm{NH}_{2}^{-}, \mathrm{OH}-\mathrm{COOH}-$, and $\mathrm{SH}$-groups) being present in sidechains of particular amino acids, the chemical coupling reactions have to address the individual demands of these functional groups for coupling. In order to extend the spectrum to a broader variety of potential coupling chemistries, bi-functional linkers have been designed for coupling of growth factors to scaffolds. Several coupling methods have recently been developed to further control the orientation of the growth factors to be immobilized including usage of cysteine-containing tags, peptide aptamers and fibrin or collagen substrates [111]. However, these methods entail protein modifications thus can also affect the outcome of individual cellular responses. Recently, Tabisz et al. [112] published a strategy for sitedirected coupling of BMP-2 to scaffolds by click-chemistry utilizing an artificial amino acid, which had been introduced during bacterial expression by amber codon suppression [113]. The constructed BMP2 variant showed the same bioactivity compared to wildtype BMP-2 and could be coupled site-directed and biologically active coupled to solid surfaces. This technique allows an interesting alternative since the linker used for coupling already gets introduced into the protein upon protein expression thus avoiding secondary modifications. Another hallmark of this technique is that the position of the artificial amino acid is not restricted to the N-terminus of BMP-2 thus allowing a positioning which certainly will not impede the binding of BMP-2 to its cognate receptors.

Engineered surfaces decorated with site-directed and covalently bound BMP-2 being immobilized via optimized linkers might represent an excellent alternative in order to maintain the growth factor's biological activity. Other surfaces, for instance gold surfaces have been first decorated with a hetero-bifunctional linker which subsequently were exposed to BMP-2. For tracking purpose, BMP-2 has been iodinated with $\mathrm{Na}^{125} \mathrm{I}$ prior to coupling. The activated surfaces were used in cell based assays using $\mathrm{C} 2 \mathrm{C} 12$ cells [114]. Also here, the covalently immobilized BMP-2 activated BMP-dependent signal transduction, thus resulting in the expected cellular responses like suppression of myotube formation and upregulated ALP expression. Specific BMP-2 binding peptides have been screened and used as part of an engineered hetero-bifunctional spacer enabling the simultaneous binding to BMP-2 and collagen [96]. In cell based assays, the bifunctional linker increased the retention of BMP-2 within a collagen matrix and led to increased osteogenic activities. But, it is not clear if BMP-2 can bind its cognate cellular receptors while still bound to the peptide or if BMP-2 has to be first released for interaction with these receptors. However, in vivo results demonstrate that the presence of the linker significantly increased osteogenic activity [96].

\section{Delivery strategies using covalently coupled BMP-2 derived peptides}

The use of peptides mimicking BMP-2 specific bioactivities might represent an attractive alternative for the costly recombinant growth factors [115]. Synthetic BMP-2 peptides might circumvent the use of native proteins that may undergo degradation and denaturation in vivo. But, due to the dimeric nature of the BMPs, the binding epitopes for the type I- (wrist epitope) and the type II receptor (knuckle epitope) exist twice. So, to achieve full receptor activation, the native ligand has to bind to two type I- and two type II-receptor chains forming a heterohexameric ligand-receptor assembly [116]. Thus, mimicking these capabilities with a simple peptide seems not feasible. However, coupling of a synthetic peptide corresponding to amino acids located within the knuckle epitope by EDC/NHS chemistry to alginate gels induced prolonged ectopic calcification for up to 7 weeks in rat calf muscle whereas BMP-2-doped collagen gel showed maximum ectopic calcification already after 3 weeks but the formed calcified ossicles disappeared after 5 weeks [117]. The peptide-functionalized alginate scaffold also induced ALP activity (ALP) in a murine osteoblast cell line. Furthermore, it could be demonstrated that upon exposure to this construct SMAD signaling is initiated resulting e.g. in the upregulation of osteopontin expression and an increased mineral deposition in murine mesenchymal stem cells [118]. Compromised bone growth often occurs in the immediate vicinity of metallic implants, leading to weakened bone quality and implant failure. BMP-2 peptides covalently bound to glass, titanium, cobalt chromium $(\mathrm{CoCr})$ and gold substrate have been shown to enhance and accelerate the growth and differentiation of osteoblasts and other cell lines. Chemical immobilization of synthetic peptides onto titanium implants was conducted to evaluate the in vitro and in vivo osteointegration capacity [119]. A peptide mimicking both, the wrist and the knuckle epitope was chemically synthesized using a so-called F-moc chemistry with an additional N-terminal modification by a cysteine-containing 
spacer which eases chemical conjugation onto implant surfaces. This peptide covalently coupled to titanium discs showed in MC3T3-E1 cells higher proliferation and upregulated expression of osteogenic markers such as ALP compared to the control disc. Importantly, the peptide modified implant material introduced into canine mandibles showed a significant increase of bone growth, thereby confirming that biochemical modifications of Ti surfaces can indeed increase the rate of bone healing compared to untreated Ti surfaces. Potentially useful findings have also been reported for $\mathrm{CoCr}$ alloy implants, where the presence of a BMP mimicking peptide (coupled via a cysteine amino acid at the N-terminus) showed twofold increase in ALP activity after 2 weeks of incubation and a fourfold increase in calcium content after 3 weeks of incubation compared to controls [120]. Peptides mimicking the knuckle epitope of BMP-2 have also been immobilized on anodized nanotubular titanium [121]. Results showed increased osteoblast adhesion compared to non-functionalized anodized titanium. This in vitro study adds anodized materialsthat holds nanometer surface textures to the growing list of materials that promote osteogenesis.

Several reports found in the more recent literature have demonstrated that surface textures in the nanometer-scale topography can influence proliferation and differentiation of embryonic and mesenchymal stem cells. Therefore, nanoscale topographies in combination with growth factors may promote proliferation or lineage differentiation of stem cells. To develop these substrates, the factors have to be immobilized directly on the surface of the substrate. One study showed that nanopatterned polyurethane acrylate (PUA) substrates uniformly coated with poly(glycidyl methacrylate) (pGMA) by initiated chemical vapor deposition (iCVD) followed by covalent immobilization of BMP-2 peptides results in a much more efficient BMP-2 peptide immobilization than e.g. physical adsorption. Results of Alizarin Red S staining, immunostaining, and quantitative real-time polymerase chain reaction (qRT-PCR) revealed that hMSCs cultured on such nanopatterned surfaces enhanced osteogenic differentiation [122]. However, despite the studies demonstrating the influence of peptide-modified surfaces on cellular behavior in vitro, there is relatively little evidence reporting their effects on osteogenesis and osteoclastogenesis (remodeling) in vivo.

\section{Comparison of gene and protein/peptide delivery strategies}

In an in vitro study, gene delivery of BMP-2 and ectopic delivery of the recombinant BMP-2 protein were directly compared. Interestingly, both approaches showed comparable mineralization results. A difference was observed in osteogenic protein expression levels where BMP-2 transfected cells expressed more osteopontin compared to the cells treated with same amount of recombinant BMP-2 protein in the cell culture medium [123]. Both, gene and protein delivery have advantages and drawbacks. Gene delivery provides supply of proteins for a relatively long time and the expression period can be controlled by inducible expression vectors. But a safety concern remains about the use of viral vectors in clinics. When non-viral vectors are considered, transfection of long DNA fragments appears difficult to perform and the efficiency may not be enough to realize complete bone restauration. In gene delivery, the protein is continuously produced by the cells and therefore stability is not an issue. However, in the development of protein delivery systems, the stability of the protein in the period of at least several weeks should always be considered and assured. Besides, the required dose and release kinetic should be assigned correctly for successful clinical outcomes.
As suggested, both systems need further improvements, more characterization of the improved systems and solid pre-clinical data to pursue with clinical trials.

\section{Future perspectives}

The complexity of tissue engineering in the field of bone regeneration inspired numerous investigators to date and as more investigations are conducted more complexity arises [124]. For the generation of innovative products more advanced engineering strategies of biomaterials probably including cells as well as growth factors are required. Controllable and reproducible production techniques of innovative materials have to be elaborated on products acting osteogenic on their own. Ideally, these materials are applied together with cells, either actively taking part in the regeneration of the bone defect and/or secreting the signalling molecules which act as initial trigger of a whole cell-cell communication cascade resulting finally in the recruitment of osteoprogenitor cells from the surrounding tissue. This initiating signal is most-likely provided by BMP-2 as described in this manuscript since application of this protein (or another osteogenic BMP) at ectopic sites (e.g. in muscular tissue) results in the formation of an ossicle by mechanisms being similar to those occurring in natural bone growth and repair. Ideally, the provided signal is sufficiently active for the period of time the bone defect needs to heal. In principal, this can be achieved best by genetically manipulated cells but due to immunological concerns, autologuous cells are required. Alternatively, the signal can be provided by the application of recombinant BMPs. Here, numerous trials have been conducted within the last decades all of which faced the same problem relying on the general (bio-) chemical properties of this class of growth factors. As these proteins can induce the formation of ectopic bone, it has to be assured that responsive tissues (e.g. muscular tissue) are not exposed to these proteins even in situations of bone fractures. For that purpose, the osteogenic BMPs are evolutionary "designed" as badly soluble proteins which additionally bind strongly to components of the extracellular matrix. Local administration of huge amounts must consequently result in a kind of precipitate rendering the majority of the protein biologically inactive. This inactive clot is typically eliminated by several environmental mechanisms. The design of $2^{\text {nd }}$ generation BMPs should, therefore, focus on protein variants which in general provide higher bioactivities over longer periods of time. This can be achieved by enhancing the individual binding affinities of the ligand to the cell surface receptors by rational structure based design. Due to enhanced binding affinities, the applied dose of the BMPs being required can be significantly reduced but the protein modification bears the risk to induce immunological responses. Another way to keep the growth factor's signalling capacities biologically active and locally in place might be provided by tight binding of the factor to suitable scaffold structures. As discussed in this review this might be realized addressing the material side (with scaffolds being optimized for BMP binding) and/or addressing the growth factor side (by a covalently bound BMP which ideally is coupled to the matrix side directly), thus enabling a robust and reproducible decoration of the chosen matrix. If initial steps of the regeneration process involve the migration of stem cells being recruited by a growth factor gradient, the coupling of this factor should - at least partially - occur via linkers which are cleavable by e.g. matrixmetalloproteinases.

In conclusion, by addressing the key problems which have been identified to date it seems feasible to create either cell-based or cell-free delivery systems for BMP-2 which in the near future can routinely be used in clinics in case of complex traumas and other cases requiring medical intervention. 


\section{Acknowledgement}

This work was supported by the European Union Seventh Framework Program FP7/2007-2013 (grant agreement No. 607051 (BIO-INSPIRE)) and the University of Wuerzburg (funding program Open Access Publishing).

\section{References}

1. Sfeir C, Ho L, Doll BA, Azari K, Holliger KO (2005) Fracture Repair. Bone regeneration and repair, biology and clinical applications. Springer $\mathrm{Pp}$ : 21-44.

2. Meling T, Harboe K, Soreide N (2009) Incidence of traumatic long-bone fractures requiring in-hospital management: a prospective age- and gender-specific analysis of 4890 fractures. Injury 40: 1212-1219. [Crossref]

3. Tosounidis T, Kontakis G, Nikolaou V, Papathanassopoulos A, Giannoudis PV (2009) Fracture healing and bone repair: an update. Trauma 11: 145-156.

4. Littenberg B, Weinstein LP, McCarren M, Mead T, Swiontkowski MF, et al. (1998) Closed fractures of the tibial shaft - A meta-analysis of three methods of treatment. $J$ Bone Joint Surg Am 80: 174-183. [Crossref]

5. Dimitriou R, Tsiridis E, Giannoudis PV, (2005) Current concepts of molecular aspects of bone healing. Injury 36: 1392-1404. [Crossref]

6. Friedlaender GE, Perry CR, Cole JD, Cook SD, Cierny G, et al. (2001) Osteogenic protein-1 (bone morphogenetic protein-7) in the treatment of tibial nonunions - A prospective, randomized clinical trial comparing rhOP-1 with fresh bone autograft. $J$ Bone Joint Surg Am 83: S151-S158.

7. Logeart-Avramoglou D, Anagnostou F, Bizios R, Petite H (2005) Engineering bone: challenges and obstacles. J Cell Mol Med 9: 72-84. [Crossref]

8. Argintar E, Edwards S, Delahay J (2011) Bone morphogenetic proteins in orthopaedic trauma surgery. Injury 42: 730-734. [Crossref]

9. Axelrad TW, Einhorn TA (2009) Bone morphogenetic proteins in orthopaedic surgery. Cytokine Growth Factor Rev 20: 481-488. [Crossref]

10. Sasso RC, LeHuec JC, Shaffrey C (2005) Iliac crest bone graft donor site pain after anterior lumbar interbody fusion: a prospective patient satisfaction outcome assessment. J Spinal Disord Tech 18 Suppl: S77-S81. [Crossref]

11. Arrington ED, Smith WJ, Chambers HG, Bucknell AL, Davino NA (1996) Complications of iliac crest bone graft harvesting. Clin Orthop Relat Res : 300-309. [Crossref]

12. Schneppendahl J, Jungbluth P, Sager M, Benga L, Herten M, et al. (2016) Synergistic effects of HBO and PRP improve bone regeneration with autologous bone grafting. Injury 47: 2718-2725. [Crossref]

13. Rodriguez IA, Growney Kalaf EA, Bowlin GL, Sell SA (2014) Platelet-rich plasma in bone regeneration: engineering the delivery for improved clinical efficacy. Biomed Res Int 2014: 392398. [Crossref]

14. Komatsu DE, Warden SJ (2010) The control of fracture healing and its therapeutic targeting: improving upon nature. J Cell Biochem 109: 302-311. [Crossref]

15. Reddi AH (2001) Bone morphogenetic proteins: from basic science to clinical applications. J Bone Joint Surg Am 83-83A Suppl 1: S1-6. [Crossref]

16. Chen D, Zhao M, Mundy GR (2004) Bone morphogenetic proteins. Growth Factors 22: 233-241. [Crossref]

17. Wozney JM, Rosen V, Celeste AJ, Mitsock LM, Whitters MJ, et al. (1988) Novel regulators of bone formation: molecular clones and activities. Science 242: 1528-1534. [Crossref]

18. Hogan BL (1996) Bone morphogenetic proteins: multifunctional regulators of vertebrate development. Genes Dev 10: 1580-1594. [Crossref]

19. Massagué J (1998) TGF-beta signal transduction. Annu Rev Biochem 67: 753-791. [Crossref]

20. Reddi AH (1998) Role of morphogenetic proteins in skeletal tissue engineering and regeneration. Nat Biotechnol 16: 247-252. [Crossref]

21. Reddi AH (2005) BMPs: from bone morphogenetic proteins to body morphogenetic proteins. Cytokine Growth Factor Rev 16: 249-250. [Crossref]

22. Li JZ, Li H, Sasaki T, Holman D, Beres B, et al. (2003) Osteogenic potential of five different recombinant human bone morphogenetic protein adenoviral vectors in the rat. Gene Ther 10: 1735-1743. [Crossref]
23. Miyazono K, Kamiya Y, Morikawa M (2010) Bone morphogenetic protein receptors and signal transduction. $J$ Biochem 147: 35-51. [Crossref]

24. Hartigan N, Garrigue-Antar L, Kadler KE (2003) Bone morphogenetic protein-1 (BMP-1). Identification of the minimal domain structure for procollagen C-proteinase activity. J Biol Chem 278: 18045-18049. [Crossref]

25. Daluiski A, Engstrand T, Bahamonde ME, Gamer LW, Agius E, et al. (2001) Bone morphogenetic protein-3 is a negative regulator of bone density. Nat Genet 27: 84-88. [Crossref]

26. Shen B, Bhargav D, Wei A, Williams LA, Tao H, et al. (2009) BMP-13 emerges as a potential inhibitor of bone formation. Int J Biol Sci 5: 192-200. [Crossref]

27. Klammert U1, Mueller TD2, Hellmann TV3, Wuerzler KK4, Kotzsch A5, et al. (2015) GDF-5 can act as a context-dependent BMP-2 antagonist. BMC Biol 13: 77. [Crossref]

28. Massagué J1, Blain SW, Lo RS (2000) TGFbeta signaling in growth control, cancer, and heritable disorders. Cell 103: 295-309. [Crossref]

29. Carcamo J, Weis FM, Ventura F, Wieser R, Wrana JL,et al. (1994) Type I receptors specify growth-inhibitory and transcriptional responses to transforming growth factor beta and activin. Mol Cell Biol 14: 3810-3821. [Crossref]

30. Ten Dijke P, Miyazono K, Heldin CH (1996) Signaling via hetero-oligomeric complexes of type I and type II serine/threonine kinase receptors. Curr Opin Cell Biol 8: 139-145. [Crossref]

31. Heldin CH, Miyazono K, ten Dijke P (1997) TGF-beta signalling from cell membrane to nucleus through SMAD proteins. Nature 390: 465-471. [Crossref]

32. Massagué J1, Seoane J, Wotton D (2005) Smad transcription factors. Genes Dev 19 2783-2810. [Crossref]

33. Nickel J1, Sebald W, Groppe JC, Mueller TD (2009) Intricacies of BMP receptor assembly. Cytokine Growth Factor Rev 20: 367-377. [Crossref]

34. Katagiri T1, Watabe T2 (2016) Bone Morphogenetic Proteins. Cold Spring Harb Perspect Biol 8. [Crossref]

35. Luo J, Tang M, Huang J, He BC, Gao JL, et al. (2010) TGFbeta/BMP type I receptors ALK1 and ALK2 are essential for BMP9-induced osteogenic signaling in mesenchymal stem cells. J Biol Chem 285: 29588-29598. [Crossref]

36. Groppe J, Greenwald J, Wiater E, Rodriguez-Leon J, Economides AN, et al. (2002) Structural basis of BMP signalling inhibition by the cystine knot protein Noggin Nature 420: 636-642. [Crossref]

37. Harrington AE, Morris-Triggs SA, Ruotolo BT, Robinson CV, Ohnuma S, et al. (2006) Structural basis for the inhibition of activin signalling by follistatin. EMBO J 25: 10351045. [Crossref]

38. Albers CE, Hofstetter W, Sebald HJ, Sebald W, Siebenrock KA, et al. (2012) L51P - A BMP2 variant with osteoinductive activity via inhibition of Noggin. Bone 51: 401-406. [Crossref]

39. Ruppert R, Hoffmann E, Sebald W (1996) Human bone morphogenetic protein 2 contains a heparin-binding site which modifies its biological activity. Eur J Biochem 237: 295-302. [Crossref]

40. Irie A, Habuchi H, Kimata K, Sanai Y (2003) Heparan sulfate is required for bone morphogenetic protein-7 signaling. Biochem Biophys Res Commun 308: 858-865. [Crossref]

41. Würzler KK, Emmert J, Eichelsbacher F, Kübler NR, Sebald W, et al. (2004) [Evaluation of the osteoinductive potential of genetically modified BMP-2 variants]. Mund Kiefer Gesichtschir 8: 83-92. [Crossref]

42. Ginn SL, Alexander IE, Edelstein ML, Abedi MR, Wixon J (2013) Gene therapy clinical trials worldwide to 2012 - an update. J Gene Med 15: 65-77. [Crossref]

43. Luo T, Zhang W, Shi B, Cheng X, Zhang Y (2012) Enhanced bone regeneration around dental implant with bone morphogenetic protein 2 gene and vascular endothelial growth factor protein delivery. Clin Oral Implants Res 23: 467-473. [Crossref]

44. Lee SJ, Kang SW, Do HJ, Han I, Shin DA, et al. (2010) Enhancement of bone regeneration by gene delivery of BMP2/Runx2 bicistronic vector into adipose-derived stromal cells. Biomaterials 31: 5652-5659. [Crossref]

45. Dalle Carbonare L1, Innamorati G, Valenti MT (2012) Transcription factor Runx2 and its application to bone tissue engineering. Stem Cell Rev 8: 891-897. [Crossref]

46. Gafni Y, Pelled G, Zilberman Y, Turgeman G, Apparailly F, et al. (2004) Gene therapy platform for bone regeneration using an exogenously regulated, AAV-2-based gene expression system. Mol Ther 9: 587-595. [Crossref] 
47. Evans CH (2012) Gene delivery to bone. Adv Drug Deliv Rev 64: 1331-1340. [Crossref]

48. Baltzer AW, Lieberman JR (2004) Regional gene therapy to enhance bone repair. Gene Ther 11: 344-350. [Crossref]

49. Pelled G, Ben-Arav A, Hock C, Reynolds DG, Yazici C, et al. (2010) Direct gene therapy for bone regeneration: gene delivery, animal models, and outcome measures. Tissue Eng Part B Rev 16: 13-20. [Crossref]

50. Ngelhardt JF, Ye X, Doranz B, Wilson JM (1994) Ablation of E2A in recombinan adenoviruses improves transgene persistence and decreases inflammatory response in mouse liver. Proc Natl Acad Sci USA 91: 6196-6200. [Crossref]

51. Buning H, Perabo L, Coutelle O, Quadt-Humme S, Hallek M (2008) Recent developments in adeno-associated virus vector technology. J Gene Med 10: 717-733. [Crossref]

52. Park J, Ries J, Gelse K, Kloss F, von der Mark K, et al. (2003) Bone regeneration in critical size defects by cell-mediated BMP-2 gene transfer: a comparison of adenoviral vectors and liposomes. Gene Ther 10: 1089-1098. [Crossref]

53. Betz OB, Betz VM, Nazarian A, Pilapil CG, Vrahas MS, et al. (2006) Direct percutaneous gene delivery to enhance healing of segmental bone defects. $J$ Bone Joint Surg Am 88: 355-365. [Crossref]

54. Egermann M, Lill CA, Griesbeck K, Evans CH, Robbins PD, et al. (2006) Effect of BMP-2 gene transfer on bone healing in sheep. Gene Ther 13: 1290-1299. [Crossref]

55. Thompson DD, Simmons HA, Pirie CM, Ke HZ (1995) FDA Guidelines and animal models for osteoporosis. Bone 17: 125S-133S. [Crossref]

56. Alhakamy NA, Nigatu AS, Berkland CJ, Ramsey JD (2013) Noncovalently associated cell-penetrating peptides for gene delivery applications. Ther Deliv 4: 741-757. [Crossref]

57. Sullivan M (2014) Histone targeted non-viral gene delivery to enhance bone repair. Grantome.

58. Jang JH, Schaffer DV, Shea LD (2011) Engineering biomaterial systems to enhance viral vector gene delivery. Mol Ther 19: 1407-1415. [Crossref]

59. Wehrhan F, Amann K, Molenberg A, Lutz R, Neukam FW, et al. (2012) PEG matrix enables cell-mediated local BMP-2 gene delivery and increased bone formation in a porcine critical size defect model of craniofacial bone regeneration. Clin Oral Implants Res 23: 805-813. [Crossref]

60. Kolk A, Haczek C, Koch C, Vogt S, Kullmer M, et al. (2011) A strategy to establish a gene-activated matrix on titanium using gene vectors protected in a polylactide coating. Biomaterials 32: 6850-6859. [Crossref]

61. Wegman F, Bijenhof A, Schuijff L, Oner FC, Dhert WJ, et al. (2011) Osteogenic differentiation as a result of BMP-2 plasmid DNA based gene therapy in vitro and in vivo. Eur Cell Mater 21: 230-242. [Crossref]

62. Chen J, Chen H, Li P, Diao H, Zhu S, et al. (2011) Simultaneous regeneration of articular cartilage and subchondral bone in vivo using MSCs induced by a spatially controlled gene delivery system in bilayered integrated scaffolds. Biomaterials 32 : 4793-4805. [Crossref]

63. Song JJ, Ott HC (2011) Organ engineering based on decellularized matrix scaffolds. Trends Mol Med 17: 424-432. [Crossref]

64. Zachos T, Diggs A, Weisbrode S, Bartlett J, Bertone A (2007) Mesenchymal stem cellmediated gene delivery of bone morphogenetic protein-2 in an articular fracture model. Mol Ther 15: 1543-1550. [Crossref]

65. Meijer GJ, de Bruijn JD, Koole R, van Blitterswijk CA (2007) Cell-based bone tissue engineering. PLoS Med 4: e9. [Crossref]

66. Banwart JC, Asher MA, Hassanein RS (1995) Iliac crest bone graft harvest donor site morbidity. A statistical evaluation. Spine (Phila Pa 1976) 20: 1055-1060. [Crossref]

67. Owen M, Friedenstein AJ (1988) Stromal stem cells: marrow-derived osteogenic precursors. Ciba Found Symp 136: 42-60. [Crossref]

68. Wu SM, Hochedlinger K (2011) Harnessing the potential of induced pluripotent stem cells for regenerative medicine. Nat Cell Biol 13: 497-505. [Crossref]

69. http://www.nature.com/news/next-generation-stem-cells-cleared-for-humantrial-1.15897

70. Horwitz EM, Gordon PL, Koo WK, Marx JC, Neel MD, et al. (2002) Isolated allogeneic bone marrow-derived mesenchymal cells engraft and stimulate growth in children with osteogenesis imperfecta: Implications for cell therapy of bone. Proc Natl Acad Sci USA 99: 8932-8937. [Crossref]
71. Kaigler D, Pagni G, Park CH, Braun TM, Holman LA, et al. (2013) Stem cell therapy for craniofacial bone regeneration: a randomized, controlled feasibility trial. Cell Transplant 22: 767-777. [Crossref]

72. Xiao C, Zhou H, Liu G, Zhang P, Fu Y, et al. (2011) Bone marrow stromal cells with a combined expression of BMP-2 and VEGF-165 enhanced bone regeneration. Biomed Mater 6: 015013. [Crossref]

73. Webber MJ1, Khan OF, Sydlik SA, Tang BC, Langer R (2015) A perspective on the clinical translation of scaffolds for tissue engineering. Ann Biomed Eng 43: 641-656. [Crossref]

74. Lin Y, Tang W, Wu L, Jing W, Li X, et al. (2008) Bone regeneration by BMP-2 enhanced adipose stem cells loading on alginate gel. Histochem Cell Biol 129: 203210. [Crossref]

75. Gao J, Dennis JE, Muzic RF, Lundberg M, Caplan AI (2001) The dynamic in vivo distribution of bone marrow-derived mesenchymal stem cells after infusion. Cells Tissues Organs 169: 12-20. [Crossref]

76. Sahin AO, Buitenhuis M (2012) Molecular mechanisms underlying adhesion and migration of hematopoietic stem cells. Cell Adh Migr 6: 39-48. [Crossref]

77. Carragee EJ, Hurwitz EL, Weiner BK (2011) A critical review of recombinant human bone morphogenetic protein-2 trials in spinal surgery: emerging safety concerns and lessons learned. Spine J 11: 471-491. [Crossref]

78. Perri B, Cooper M, Lauryssen C, Anand N (2007) Adverse swelling associated with use of rh-BMP-2 in anterior cervical discectomy and fusion: a case study. Spine $J 7$ : 235-239. [Crossref]

79. Woo EJ, Burwen DR, Gatumu SN, Ball R; Vaccine Adverse Event Reporting System Working Group (2003) Extensive limb swelling after immunization: reports to the Vaccine Adverse Event Reporting System. Clin Infect Dis 37: 351-358. [Crossref]

80. King WJ, Krebsbach PH (2012) Growth factor delivery: how surface interactions modulate release in vitro and in vivo. Adv Drug Deliv Rev 64: 1239-1256. [Crossref]

81. Patel ZS, Yamamoto M, Ueda H, Tabata Y, Mikos AG (2008) Biodegradable gelatin microparticles as delivery systems for the controlled release of bone morphogenetic protein-2. Acta Biomater 4: 1126-1138. [Crossref]

82. Lutolf MP, Weber FE, Schmoekel HG, Schense JC, Kohler T, et al. (2003) Repair of bone defects using synthetic mimetics of collagenous extracellular matrices. Nat Biotechnol 21: 513-518. [Crossref]

83. Shekaran A, García JR, Clark AY, Kavanaugh TE, Lin AS, et al. (2014) Bone regeneration using an alpha 2 beta 1 integrin-specific hydrogel as a BMP-2 delivery vehicle. Biomaterials 35: 5453-5461. [Crossref]

84. Boerckel JD1, Kolambkar YM, Dupont KM, Uhrig BA, Phelps EA, et al. (2011) Effect of protein dose and delivery system on BMP-mediated bone regeneration. Biomaterials 32: 5241-5251. [Crossref]

85. Lee JW, Kang KS, Lee SH, Kim JY, Lee BK, et al. (2011) Bone regeneration using a microstereolithography-produced customized poly(propylene fumarate)/diethyl fumarate photopolymer 3D scaffold incorporating BMP-2 loaded PLGA microspheres. Biomaterials 32: 744-752. [Crossref]

86. Hernández A, Sánchez E, Soriano I, Reyes R, Delgado A, et al. (2012) Material-related effects of BMP-2 delivery systems on bone regeneration. Acta Biomater 8: 781-791. [Crossref]

87. Young CL, Britton ZT, Robinson AS (2012) Recombinant protein expression and purification: a comprehensive review of affinity tags and microbial applications. Biotechnology Journal 7: 620-634. [Crossref]

88. Terpe K (2003) Overview of tag protein fusions: from molecular and biochemical fundamentals to commercial systems. Appl Microbiol Biotechnol 60: 523-533. [Crossref]

89. Magdeldin S (2012) Affinity Chromatography. InTech.

90. Steen Redeker E, Ta DT, Cortens D, Billen B, Guedens W, et al. (2013) Protein engineering for directed immobilization. Bioconjug Chem 24: 1761-1777. [Crossref]

91. Bessa PC, Cerqueira MT, Rada T, Gomes ME, Neves NM, et al. (2009) Expression, purification and osteogenic bioactivity of recombinant human BMP-4, -9, -10, -11 and -14. Protein Expr Purif 63: 89-94.

92. Gründer T1, Gaissmaier C, Fritz J, Stoop R, Hortschansky P, et al. (2004) Bone morphogenetic protein (BMP)-2 enhances the expression of type II collagen and aggrecan in chondrocytes embedded in alginate beads. Osteoarthritis Cartilage 12 559-567. [Crossref] 
93. Yuvaraj S, Al-Lahham SH, Somasundaram R, Figaroa PA, Peppelenbosch MP, et al. (2012) coli-produced BMP-2 as a chemopreventive strategy for colon cancer: a proofof-concept study. Gastroenterol Res Pract 2012: 895462.

94. Wehrhan F, Amann K, Molenberg A, Lutz R, Neukam FW, et al. (2013) Critical size defect regeneration using PEG-mediated BMP-2 gene delivery and the use of cell occlusive barrier membranes - the osteopromotive principle revisited. Clin Oral Implants Res 24: 910-920.

95. Zhao Y, Zhang J, Wang X, Chen B, Xiao Z, et al. (2010) The osteogenic effect of bone morphogenetic protein-2 on the collagen scaffold conjugated with antibodies. $J$ Controlled Release 141: 30-37. [Crossref]

96. Hamilton PT1, Jansen MS, Ganesan S, Benson RE, Hyde-Deruyscher R, et al. (2013) Improved bone morphogenetic protein- 2 retention in an injectable collagen matrix using bifunctional peptides. Plos One 8: e70715. [Crossref]

97. https://www.google.com/patents/US7977313

98. Sasisekharan R1, Ernst S, Venkataraman G (1997) On the regulation of fibroblast growth factor activity by heparin-like glycosaminoglycans. Angiogenesis 1: 45-54. [Crossref]

99. Kim SE, Song SH, Yun YP, Choi BJ, Kwon IK, et al. (2011) The effect of immobilization of heparin and bone morphogenic protein-2 (BMP-2) to titanium surfaces on inflammation and osteoblast function. Biomaterials 32: 366-373. [Crossref]

100. Lee DW, Yun YP, Park K, Kim SE (2012) Gentamicin and bone morphogenic protein-2 (BMP-2)-delivering heparinized-titanium implant with enhanced antibacterial activity and osteointegration. Bone 50: 974-982. [Crossref]

101. Kim SE, Yun YP, Han YK, Lee DW, Ohe JY, et al. (2014) Osteogenesis induction of periodontal ligament cells onto bone morphogenic protein-2 immobilized PCL fibers. Carbohydr Polym 99: 700-709. [Crossref]

102. Kim TH, Yun YP, Park YE, Lee SH, Yong W, et al. (2014) In vitro and in vivo evaluation of bone formation using solid freeform fabrication-based bone morphogenic protein-2 releasing PCL/PLGA scaffolds. Biomedical Materials 9: 025008. [Crossref]

103. Guzmán R, Nardecchia S, Gutiérrez MC, Ferrer ML, Ramos V, et al. (2014) Chitosan scaffolds containing calcium phosphate salts and rhBMP-2: in vitro and in vivo testing for bone tissue regeneration. Plos One 9: e87149. [Crossref]

104. Chilkoti A, Tan PH, Stayton PS (1995) Site-directed mutagenesis studies of the highaffinity streptavidin-biotin complex: contributions of tryptophan residues 79,108 , and 120. Proc Natl Acad Sci USA 92: 1754-1758. [Crossref]

105. Uludag H, Golden J, Palmer R, Wozney JM (1999) Biotinated bone morphogenetic protein-2: In vivo and in vitro activity. Biotechnol Bioeng 65: 668-672. [Crossref]

106. Wiemann M, Jennissen HP, Rumpf H, Winkler L, Chatzinikolaidou M, et al. (2002) A reporter-cell assay for the detection of BMP-2 immobilized on porous and nonporous materials. J Biomed Mater Res 62: 119-127. [Crossref]

107. Lagunas A, Comelles J, Oberhansl S, Hortigüela V, Martínez E, et al. (2013) Continuous bone morphogenetic protein-2 gradients for concentration effect studies on $\mathrm{C} 2 \mathrm{C} 12$ osteogenic fate. Nanomedicine 9: 694-701. [Crossref]

108. Schliephake H, Botel C, Forster A, Schwenzer B, Reichert J, et al. (2012) Effect of oligonucleotide mediated immobilization of bone morphogenic proteins on titanium surfaces. Biomaterials 33: 1315-1322. [Crossref]
109. Chatzinikolaidou M, Lichtinger TK, Muller RT, Jennissen HP (2010) Peri-implant reactivity and osteoinductive potential of immobilized rhBMP-2 on titanium carriers. Acta biomaterialia 6: 4405-4421. [Crossref]

110. Bauer S, Park J, Pittrof A, Song YY, von der Mark K, et al. (2011) Covalent functionalization of TiO2 nanotube arrays with EGF and BMP-2 for modified behavior towards mesenchymal stem cells. Integr Biol (Camb) 3: 927-936. [Crossref]

111. Kashiwagi K1, Tsuji T, Shiba K (2009) Directional BMP-2 for functionalization of titanium surfaces. Biomaterials 30: 1166-1175. [Crossref]

112. Tabisz B, Schmitz W, Schmitz M, Luehmann T, Heusler E, et al. (2017) Site-Directed Immobilization of BMP-2: Two Approaches for the Production of Innovative Osteoinductive Scaffolds. Biomacromolecules 18: 695-708. [Crossref]

113. Wang L, Magliery TJ, Liu DR, Schultz PG (2000) A new functional suppressor tRNA/aminoacyl-tRNA synthetase pair for the in vivo incorporation of unnatural amino acids into proteins. $J$ Am Chem Soc 122: 5010-5011.

114. Pohl T, Boergermann JH, Schwaerzer GK, Knaus P, Cavalcanti-Adam EA (2012) Surface immobilization of bone morphogenetic protein 2 via a self-assembled monolayer formation induces cell differentiation. Acta Biomater 8: 772-780. [Crossref]

115. Suzuki Y, Tanihara M, Suzuki K, Saitou A, Sufan W, et al. (2000) Alginate hydrogel linked with synthetic oligopeptide derived from BMP-2 allows ectopic osteoinduction in vivo. J Biomed Mater Res 50: 405-409. [Crossref]

116. Heinecke K, Seher A, Schmitz W, Mueller TD, Sebald W, et al. (2009) Receptor oligomerization and beyond: a case study in bone morphogenetic proteins. BMC Biol 7: 59. [Crossref]

117. Saito A, Suzuki Y, Ogata S, Ohtsuki C, Tanihara M (2004) Prolonged ectopic calcification induced by BMP-2-derived synthetic peptide. J Biomed Mater Res A 70: 115-121. [Crossref]

118. Madl CM, Mehta M, Duda GN, Heilshorn SC, Mooney DJ (2014) Presentation of BMP-2 mimicking peptides in 3D hydrogels directs cell fate commitment in osteoblasts and mesenchymal stem cells. Biomacromolecules 15: 445-455. [Crossref]

119. Seol YJ, Park YJ, Lee SC, Kim KH, Lee JY, et al. (2006) Enhanced osteogenic promotion around dental implants with synthetic binding motif mimicking bone morphogenetic protein (BMP)-2. J Biomed Mater Res A 77: 599-607. [Crossref]

120. Poh CK, Shi Z, Tan XW, Liang ZC, Foo XM, et al. (2011) Cobalt chromium alloy with immobilized BMP peptide for enhanced bone growth. J Orthop Res 29: 14241430. [Crossref]

121. Balasundaram G, Yao C, Webster TJ (2008) $\mathrm{TiO}_{2}$ nanotubes functionalized with regions of bone morphogenetic protein-2 increases osteoblast adhesion. $J$ Biomed Mater Res A 84: 447-453. [Crossref]

122. Kim MJ, Lee B, Yang K, Park J, Jeon S, et al. (2013) BMP-2 peptide-functionalized nanopatterned substrates for enhanced osteogenic differentiation of human mesenchymal stem cells. Biomaterials 34: 7236-7246. [Crossref]

123. Meinel L, Hofmann S, Betz O, Fajardo R, Merkle HP, et al. (2006) Osteogenesis by human mesenchymal stem cells cultured on silk biomaterials: comparison of adenovirus mediated gene transfer and protein delivery of BMP-2. Biomaterials 27 : 4993-5002. [Crossref]

124. Place ES, Evans ND, Stevens MM (2009) Complexity in biomaterials for tissue engineering. Nat Mater 8: 457-470. [Crossref]

Copyright: $@ 2017$ Mumcuoglu D. This is an open-access article distributed under the terms of the Creative Commons Attribution License, which permits unrestricted use, distribution, and reproduction in any medium, provided the original author and source are credited. 